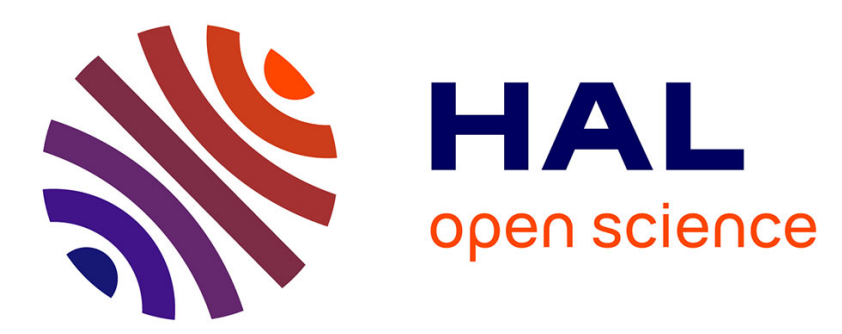

\title{
Shrinking and Splitting of drainage basins in orogenic landscapes from the migration of the main drainage divide
}

Stéphane Bonnet

\section{- To cite this version:}

Stéphane Bonnet. Shrinking and Splitting of drainage basins in orogenic landscapes from the migration of the main drainage divide. Nature Geoscience, 2009, 2, pp.766 - 771. 10.1038/ngeo666 . insu00429309

\section{HAL Id: insu-00429309 \\ https://hal-insu.archives-ouvertes.fr/insu-00429309}

Submitted on 3 Nov 2009

HAL is a multi-disciplinary open access archive for the deposit and dissemination of scientific research documents, whether they are published or not. The documents may come from teaching and research institutions in France or abroad, or from public or private research centers.
L'archive ouverte pluridisciplinaire HAL, est destinée au dépôt et à la diffusion de documents scientifiques de niveau recherche, publiés ou non, émanant des établissements d'enseignement et de recherche français ou étrangers, des laboratoires publics ou privés. 


\title{
1 Shrinking and Splitting of drainage basins in orogenic \\ 2
}

\author{
STEPHANE BONNET ${ }^{1,2}$ \\ ${ }^{1}$ Géosciences Rennes, Université de Rennes 1, Campus de Beaulieu, 35042 Rennes Cedex, France \\ ${ }^{2}$ CNRS/INSU, UMR 6118, Campus de Beaulieu, 35042 Rennes Cedex, France \\ e-mail: stephane.bonnet@univ-rennes1.fr
}

Phone +33223235690

Fax +33223236780

Climate, and in particular the spatial pattern of precipitation, is thought to affect the topographic and tectonic evolution of mountain belts through erosion ${ }^{1-5}$. Numerical model simulations of landscape erosion controlled by-horizontal tectonic motion ${ }^{6}$ or orographic precipitation $^{7,8}$ result in the asymmetric topography that characterizes most natural mountain belts6, and in a continuous migration of the main drainage divide. The effects of such a migration have, however, been challenging to observe in natural settings6. Here I document the effects of a lateral precipitation gradient on a landscape undergoing constant uplift in a laboratory modelling experiment. In the experiment, the drainage divide migrates towards the drier, leeward side of the mountain range, causing the drainage basins on the leeward side to shrink and split into smaller basins. This mechanism results in a progressively increasing number of drainage basins on the leeward side of the mountain range as the divide migrates, such that the expected relationship between the spacing of drainage basins and the location of the main drainage divide ${ }^{9}$ is maintained. I propose that this mechanism could clarify the drainage divide migration and topographic asymmetry found in active orogenic mountain ranges, as exemplified by the Aconquija Range of Argentina ${ }^{10}$.

In separating the water flux coming from precipitation between the drainage basins located over the two opposite flanks of topography, the main drainage divide is an important physiographic element of orogen topography. When associated with an orographic effect, drainage divide delineates domains where differences in precipitation and hydrologic regimes may directly influence erosional processes that shape topography and thus, landscape forms ${ }^{7,8}$, erosion rates ${ }^{11}$ and, over a geological time-scale, the rates and patterns of exhumation of metamorphic rocks ${ }^{4}$ and internal strain $^{3}$ within the orogens. The continuous migration of the drainage divide in orogens, as observed in the numerical modelling of surface processes when erosion is forced by tectonic advection ${ }^{6}$ or orographic precipitations ${ }^{7,8}$, is hardly demonstrable in natural settings. Only the observation that natural orogens usually exhibit asymmetric topography ${ }^{6}$ supports numerical results. In natural settings, divide dynamics have only been inferred in local and timely-discontinuous shifts in their location consecutive to river capture events ${ }^{12}$. They have also occasionally been inferred from changes in sediment content at the drainage basin outlets ${ }^{13}$. This emphasizes the need to find criteria that can be used to better investigate divide migration in orogens. 
The experimental modelling of erosion is a powerful tool to investigate landscape dynamics. It indicates that landscapes may be more dynamic than the numerical models suggest ${ }^{14}$, e.g. when considering the evolution of ridge crests, and it has already been used to demonstrate that some landscape features, such as long narrow perched drainages, form in areas of actively migrating divides $^{15}$. Figure 1 shows an example of divide migration in the laboratory modelling of landscape dynamics ${ }^{16,17}$ forced by uniform uplifting of the eroded material but with a precipitation gradient (see the Methods section). In this experiment, the precipitation gradient was applied after a first phase of uniform precipitation and the attainment of a steady state between erosion and uplift ${ }^{16,17}$ (Fig. 1). During this initial phase, the topography is symmetric overall (Fig. 1a, Fig. 1C), and the elevation of the divide remains constant with time (Fig. 1a, Fig. 1b). Application of the precipitation gradient induces migration of the drainage divide toward the drier side of the landscape and development of an asymmetric topography (Fig. 1), as also observed numerically ${ }^{7,8}$. The divide is simultaneously uplifted (Fig. 1b) such that the mean topographic slope of the wetter side of the landscape remains constant during its elongation (Fig. 1a). At no time is the establishment of a new steady-state observed in this experiment (Fig. 1b), nor is the divide position pinned (Fig. 1C). The progressive shortening of the drier side of the landscape consecutive to divide migration results in an increase in the roughness of the surface and in a very unstable landscape (Fig. 2).This leads to an original mechanism that splits the drainage networks: each initial drainage network splits into two individual networks that become progressively separated by the growth of a new hillcrest (Figure 2). Through this mechanism, the numbers of drainage basins extending to the main divide increases during divide migration.

Given the pattern of rainfall and once the precipitation gradient is applied, the migration of the drainage divide induces a continuous decrease in the mean runoff within the drainage basins located on the drier side of the landscape (Fig. 3b). There, the area of the drainage basins decreases because of the combination of two processes: a continuous size reduction (a direct consequence of the divide migration), and an abrupt size reduction consecutive to the split of the drainage network and the individuation of two drainage basins from a previous single one. Overall, the decrease of the drainage basins' size correlates with a steepening of their channels (Fig. 3c). The detailed analysis of the experimental drainage basins' response to the rainfall gradient documents a two-step evolution of the channels, before and after splitting occurred (Fig. 3). In a first phase, from the establishment of the precipitation gradient up to the splitting, an erosion wave propagates upward within the former steady-state channels (Fig. 3c). It generates the upstream migration of a knickpoint, defined as an abrupt change in the channel gradient, which separates an upstream segment passively uplifted from a downstream segment steepened to a new steady-state gradient (Fig. 3c). This mechanism has already been described analytically ${ }^{18,19}$ and experimentally ${ }^{16}$. After the erosion wave has swept the entire channels, channel steepening drives a temporary steady-state between uplift and erosion (Fig. $3 \mathrm{c}$,d). This temporary steady-state only concerns channels and not the whole landscape (Fig. 1), as hillcrests are passively uplifted at the same time (Fig. 3d). In a second phase, after the split of drainage networks, a profound disruption of the temporary steady-state of the channels occurs, preventing the establishment of new steady-state conditions. From splitting onward, the channels continuously steepen as they shorten because of divide migration (Fig. 3c). Figure $3 \mathrm{~d}$ shows the elevation history of three geographically-fixed spatial points of the model, illustrating how complex elevation histories can be during this sequence of landscape changes. Specifically, it illustrates how 
some parts of the floodplains are uplifted and transformed into a divide separating the two newlyformed drainage basins after splitting has occurred.

As for natural channels ${ }^{20}$, the hydraulic properties, width, depth, cross-sectional area, mean flow velocity, hydraulic radius and wet perimeter all increase with water discharge in the laboratory ${ }^{21}$. By continually reducing the discharge within drainage basins, divide migration consequently drives a narrowing of the channels so that erosion is progressively localized within the floodplains during divide migration, resulting in their abandoned parts being uplifted (Fig. 3d). Channels have also been shown to narrow as they steepen, theoretically ${ }^{22}$ and in the field $d^{23}$, so that narrowing may also be driven by the steepening of the channels described here (Fig. 3c). Even if channels cannot be observed directly during experiments because of opacity during rainfall, a careful examination at the time-step evolution of the experimental landscape (Fig. 2) shows that the location of the newly-formed trunk channels after splitting is intimately linked to the former geometry of the upstream tributaries of the channel network. As illustrated in Figure 4, the network splitting mechanism most likely occurs at the tributaries' junction and lies in the combination of channel narrowing associated with ongoing uplift and reduced erosion rates in the interfluves area (Fig 3d). This enables flows coming from the tributaries to disconnect in place of a former single channel.

The mechanism of network splitting proposed here led to transient dynamics that are exemplified by the Sierra Aconquija range in the Sierras Pampeanas province of NW Argentina ${ }^{10}$ (Fig. 5). The Aconquija is an uplifted basement range, bounded by active high-angle reverse faults on one or both sides against Neogene sedimentary basins ${ }^{10,24-25}$ (Fig. 5). Thermochronological data ${ }^{10}$ indicates the start of the rapid exhumation of the range $\sim 6 \mathrm{Ma}$ ago and a total rock uplift of at least 6.4-11.1 km over the last 6 Myr. It presently forms a prominent landscape above its adjacent foreland plains, reaching elevations $>5 \mathrm{~km}$. Because of its location on the eastern front of the Andes, representing a major topographic barrier to the moisture flux coming from the Atlantic Ocean ${ }^{26}$, the Sierra Aconquija is an orographic barrier: its eastern flank receives much more precipitation $(>2 \mathrm{~m}$ $\mathrm{yr}^{-1}$ ) than its western one $\mathrm{e}^{10,25-26}$ (Fig. 5), where an arid climate prevails. To the west of the Aconquija, climate proxies indicate that aridification initiated $3 \mathrm{Myr} \mathrm{ago}^{27}$. It is interpreted as reflecting the onset of the orographic barrier via a surface uplift of the Aconquija ${ }^{27}$, which occurred when the topography reached elevations of 2-2.5 $\mathrm{km}$ in the $\mathrm{Andes}^{10}$. Compared to modern maximum elevations of the range, this suggests that the divide of the Aconquija has been uplifted (surface uplift) by 3-3.5 km during the last $3 \mathrm{Myr}^{10}$. The Aconquija presently shows a jagged topography characterized by deeply-incised, regularly-spaced, transverse rivers. Overall, its topography is asymmetric and its drainage divide shows an offset position toward the drier side of the range (Fig. 5), with a fractional divide position ${ }^{6}$ of 0.6-0.7. The drainage networks on the drier leeward flank of the range show multiple examples of unusual landscape configurations (Fig. $5 \mathrm{C}$ ), indicating that the split of drainage networks likely occurred following the mechanism described experimentally (Fig. 4). It implies the migration of the main divide of the Aconquija toward the drier flank of the range and the progressive development of its topographic asymmetry. The asymmetric development of topography would not exist in the absence of asymmetry of at least one forcing parameter ${ }^{6}$ : rock erodability, tectonic forcing or climatic conditions. Differences in erodability are not likely to be the cause of the asymmetry because variations in topography do not coincide with lithologic ones. Horizontal tectonic motions are likely negligible in the Aconquija case because of the high-angle of 
the bounding faults ${ }^{10,24}$ and because the range is bounded by opposite reverse faults on both sides in the area considered (Fig. 5). The development of the topographic asymmetry of the Aconquija is most likely the direct result of climate, through the establishment of the orographic rainfall gradient, following a mechanism of orographic influence on asymmetry development also observed numerically ${ }^{7,8}$. Indirectly ${ }^{28}$, climatic variations led to different sequences of aggradation and degradation events in sedimentary basins flanking the range and resulted in a base-level more elevated on the leeward side than on the windward one ${ }^{10}$, a phenomenon that may also have influenced topographic asymmetry development. Assuming a symmetric topography at the onset of orographic barrier development $3 \mathrm{Myr}$ ago $^{27}$, the subsequent estimated rate of divide migration is 0.8-1.5 $\mathrm{mm} \mathrm{yr}^{-1}$, of the same order of magnitude as uplift rates.

In natural settings, the spacing of drainage basin outlets along mountain fronts is remarkably regular, regardless of their tectonic and climatic setting $\mathrm{s}^{9,29}$. With the exception of some Himalayan catchments ${ }^{9}$, most landscapes obey a single empirical scaling law, which relates outlet spacing to half the distance between the main divide and the range front ${ }^{9,29}$. As studied here, the experimental landscapes follow a similar law (see Supplementary Figure). In the context of widening mountain belts, the preservation of the spacing ratio implies that processes such as river capture or drainage divide collapse decrease the number of outlets during the lengthening of drainage basins ${ }^{9,29}$. The present study demonstrates that the reverse occurs during the shortening of drainage basins induced by divide migration, and the split of drainage networks described here represents the only existing mechanism that allows to increase the number of drainage basins at mountain fronts and to maintain their spacing ratio. Experiments illustrate how complex the elevation history of a spatial point of a landscape can be. Many issues must still be investigated to better understand the mechanism of drainage splitting, both in experiments and nature; the channel behaviour at the tributaries' junction in the context of reducing discharge is likely the most important. However, the identification of the splitting mechanism provides the first opportunity to investigate drainage divide migration in active orogens through the coeval dynamics of the associated drainage networks.

\section{METHODS}

Experiments were performed in the Modelling Laboratory at Geosciences Rennes/University of Rennes1. I used a paste of pure silica grains (mean grain size of $20 \mu \mathrm{m}$ ) mixed with water. The water content was chosen such that the paste has a vertical angle of rest and water infiltration was negligible. The paste was introduced into a box with a vertically adjustable base, whose movements were driven by a screw and a computer-controlled stepping motor. The internal area of the box was $60 \times 40 \mathrm{~cm}$ and $50 \mathrm{~cm}$ deep. During an experimental run, the base of the box was raised at a constant rate and pushed the paste outside the top of the box at a rate defined as the uplift rate. Precipitation was generated by a system of four sprinklers that delivered water droplets with diameter of $\sim 10 \mu \mathrm{m}$, which was small enough to avoid any splash dispersion at the surface of the model. The precipitation rate at the surface of the model could be controlled by changing the water pressure and the configuration of the sprinklers. Precipitation was measured by collecting water in 20 pans at the location of the model before and after each experimental run. The coefficient of variation (standard deviation/mean) of rainfall rates for measurement intervals of 10 minutes is less than $5 \%$ for the 
experiment performed here. The surface of the model was eroded by running water at its surface and grain detachment and transport occurred mainly by shear detachment through surface runoff. The topography was measured by using a commercial stereogrammetric camera system, which has a precision of $\sim 20 \mu \mathrm{m}$. The raw data were gridded to produce DEMs with a pixel size of $0.5 \mathrm{~mm}$.

Inherently to all laboratory modellings of landscape dynamics (at University of Rennes 1: see refs. 16, 17, 21 and at University of Minnesota: see ref. 14 and 15), experiments such as those developed here are oversimplifications of natural systems. Oversimplification is imposed by the difficulty to model some particular processes (vegetation dynamics, weathering processes and chemical erosion, atmospheric processes, etc.) but it is also a choice that is motivated by the necessity to understand the influence of each forcing parameter before investigating more complex systems. More importantly, experiments cannot be scaled to nature because of the impossibility to downscale natural conditions to the laboratory (for examples, see refs. 15, 17, 21). Because of these scale distortions, modelling of landscape dynamics is only experimental and not analog ${ }^{15-17}$. However, there is a consensus about the qualitative relevance of these models ${ }^{15-17}$, which permits a much more dynamic view of landscape evolution than the usual numerical models (see ref. 15).

\section{References}

1. Beaumont, C., Fullsack, P. \& Hamilton, J. Erosional control of active compressional orogens. In Thrust Tectonics (ed McClay, K. R.) 1-18 (New York: Chapman Hall, 1992)

2. Hoffman, P. F. \& Grotzinger, J. P. Orographic precipitation, erosional unloading, and tectonic style. Geology 21, 195-198 (1993).

3. Willett, S. D. Orogeny and orography: The effects of erosion on the structure of mountain belts. J. Geophys. Res 104, 28957-28981 (1999).

4. Montgomery, D. R., Balco G. \& Willett, S. D. Climate, tectonics, and the morphology of the Andes. Geology 29, 579-582 (2001).

5. Whipple, K.X. The influence of climate on the tectonic evolution of mountain belts. Nature Geosci. 2, 97-104 (2009).

6. Willett, S. D., Slingerland, R. \& Hovius, N. Uplift, shortening, and steady-state in active mountain belts. Am. J. Sci. 301, 455-485 (2001).

7. Roe, G. H., Montgomery, D. R. \& Hallet, B. Orographic precipitation and the relief of mountain ranges. J. Geophy. Res. 108 (2003) (doi:10.1029/2001JB001521).

8. Anders, A. M., Roe, G. H., Montgomery, D. R. \& Hallet, B. Influence of precipitation phase on the form of mountain ranges. Geology 36, 479-482 (2008).

9. Hovius, N. Regular spacing of drainage outlets from linear mountain belts. Basin Res. 8, 29-44 (1996).

10. Sobel, E. R. \& Strecker, M. R. Uplift, exhumation and precipitation: Tectonic and climatic control of late Cenozoic landscape evolution in the northern Sierras Pampeanas, Argentina. Basin Res. 15, 431-451 (2003).

11. Reiners, P. W., Ehlers, T. A., Mitchell, S. G. \& Montgomery, D. R. Coupled spatial variations in precipitation and long-term erosion rates across the Washington Cascades. Nature 426, 645647 (2003). 
12. Craw, D., Nelson, E. \& Koons, P. O. Structure and topographic evolution of the Main Divide in the Landsborough-Hopkins area of the Southern Alps, New Zealand. New Zealand J. Geol. Geophys. 46, 553-562 (2003).

13. Kuhlemann, J., Frisch, W., Dunkl, I., Székely, D. \& Spiegel C. Miocene shifts of the drainage divide in the Alps and their foreland basin. Z. Geomorph. N. F. 45, 239-265 (2001).

14. Hasbargen, L. E. \& Paola, C. Landscape instability in an experimental drainage basin. Geology 28, 1067-1070 (2000).

15. Hasbargen, L. E. Some Characteristics of Drainage Basin Realignment. Eos Trans. AGU, 87(36), Jt. Assem. Suppl., Abstract H53F-04 (2006).

16. Bonnet, S. \& Crave, A. Landscape response to climate change: Insights from experimental modeling and implications for tectonic versus climatic uplift of topography. Geology 31, 123126 (2003).

17. Lague, D., Crave, A. \& Davy, P. Laboratory experiments simulating the geomorphic response to tectonic uplift. J. Geophys. Res 108 (2003) (doi:10.1029/2002JB001893).

18. Whipple, K. X. \& Tucker, G. E. Dynamics of the stream-power river incision model: Implications for height limits of mountain ranges, landscape response timescales, and research needs. J. Geophys. Res. 104, 17661-17674 (1999).

19. Whipple, K. X. Fluvial landscape response time: How plausible is steady-state denudation? Am. J. Sci. 301, 313-325 (2001).

20. Leopold, L. B. \& Maddock Jr, T. The hydraulic geometry of stream channels and some physiographic implications. U. S. Geol Surv. Prof. Pap. 252 (1953).

21. Turowski, J. M., Lague, D., Crave, A. \& Davy, P. Experimental channel response to tectonic uplift. J. Geophys. Res 111 (2006) (doi:10.1029/2005JF000306).

22. Wobus, C. W., Tucker, G. E. \& Anderson, R. S. Self-formed bedrock channels. Geophys. Res. Lett. 33 (2006) (doi:10.1029/2006GL027182).

23. Whittaker, A. C., Cowie, P. C., Attal, M., Tucker, G. E. \& Roberts, G. P. Bedrock channel adjustment to tectonic forcing: Implications for predicting river incision rates. Geology 35, 103-106 (2007).

24. Strecker, M. R., Cerveny, P., Bloom, A. L. \& Malizia, D. late Cenozoic tectonism and landscape development in the foreland of the Andes: Northern Sierras Pampeanas $\left(26^{\circ} \mathrm{S}-28^{\circ} \mathrm{S}\right)$, Argentina. Tectonics 8, 517-534 (1989).

25. Strecker, M. R., Alonso, R. N., Bookhagen, B., Carrapa, B., Hilley, G. E., Sobel, E. R. \& Trauth, M. H. Tectonics and climate of the Southern Central Andes. Ann. Rev. Earth Planet. Sci. 35, 747-787 (2007).

26. Bookhagen, B. \& Strecker, M. R. Orographic barriers, high-resolution TRMM rainfall, and relief variations along the eastern Andes. Geophys. Res. Lett. 35 (2008) (doi:1029/2007GL032011).

27. Kleinert, K. \& Strecker, M. R. Climate change in response to orographic barrier uplift: Paleosol and stable isotope evidence from the late Neogene Santa Maria basin, northwestern Argentina. Geol. Soc. Am. Bull. 113, 728-742 (2001).

28. Sobel, E. R., Hilley, G. E. \& Strecker, M. R. Formation of internally drained contractional basins by aridity-limited bedrock incision. J. Geophys. Res. 108 (2003) (doi:10.1029/2002JB001883).

29. Talling, P. J., Stewart, M. D., Stark, C. P., Gupta, S. \& Vincent, S. J. Regular spacing of drainage outlets from linear faults blocks. Basin Res. 9, 275-302 (1997). 
30. Moyano, M. S. Análisis regional del emplazamiento, sedimentación y evolución sintectónica de los abanicos aluviales cuaternarios de las Sierras Pampeanas Nordoccidentales. Catamarca y Tucumán. Unpublished PhD thesis, Facultad de Ciencias Naturales e IML - Universidad Nacional de Tucumán, 209 p. (2009).

Correspondence and requests for materials should be addressed to S.B.

\section{Acknowledgements}

I would like to thank J.-J. Kermarrec for his technical assistance with the experiments and C. Andermann and M. Gaboriau for their friendly help during the experimental runs. This work benefited from discussions with B. Bookhagen, P.R. Cobbold, I. Coutand, A. Crave, P. Davy, D. Gapais, D. Lague and S. Moyano. Special thanks to P. Davy for providing and constantly improving the GridVisual software. This work was funded by the Institut National des Sciences de I'Univers (INSUCNRS) through the "Reliefs de la Terre" research programme.

\section{Figure captions}

Figure 1 Laboratory modelling of landscape dynamics under uniform uplift of the eroded material and lateral precipitation gradient. The uplift rate is $12 \mathrm{~mm} \mathrm{~h}^{-1}$. a, Evolution of topographic profiles. Each line is the mean elevation along a $20-\mathrm{cm}$-wide transverse swath calculated from DEMs. The patterns of rainfall forcing are also shown. Note the superimposition of the topographic profiles at the end of the first step, which implies a steady-state between uplift and erosion ${ }^{16,17}$. $\mathbf{b}$, Evolution of mean and maximum (drainage divide) elevations of the model. Error bars give the standard deviation of the mean. The solid line indicates the amount of applied uplift, i.e. elevation of the model if no erosion occurred. The line is only interrupted upward for graphical convenience; uplift forcing was applied during the entire experiment at a constant rate. Note that the constancy of mean and maximum elevations during the first evolution step implies a steady-state between uplift and erosion ${ }^{16,17}$ and the absence of a steady-state from the application of the rainfall gradient. c, Evolution of the normalized divide position ${ }^{6}$, highlighting the asymmetry development from the application of the rainfall gradient. $\mathbf{d}$, Photographs of three stages of landscape evolution, taken at steady-state $\left(600^{\prime}\right)$ and during the subsequent divide migration (940 and $\left.1300^{\prime}\right)$. The model width on the view is $400 \mathrm{~mm}$.

Figure 2 Landscape response to main drainage divide (MDD) migration. The images are successive shaded surface views of the driest side of the model DEMs (views are $\sim 200 \times 300 \mathrm{~mm}$ ) with superposition of drainage networks as extracted from DEMs using a steepest-slope flow routine. The width of individual channels on the images only depends on the pixel size of the DEMs $(0.5 \mathrm{~mm})$ and does not reflect the width dependency with discharge or slope. The images illustrate the migration of the MDD, the induced shortening of the drainage basins and the split of their drainage network. The splitting mechanism induced the abandonment of former parts of the landscape where tributaries 
were initially connected (open arrows) and their subsequent uplift, leading to the development of new hillcrests (solid arrows). This mechanism consequently leads to the individuation of two drainage basins from a single former one.

Figure 3 Detailed geomorphic evolution of a drainage basin. a, Photographs taken from the driest side of the experimental landscape showing the location of the studied drainage basin (orange arrow) and of some selected points of the landscape whose elevation history is detailed. $\mathbf{b}$, Timeevolution of mean runoff within the selected drainage basin, water flux at outlet and basin size. c, Time-evolution of the longitudinal profile of the main trunk channel. The stack of longitudinal profiles until 600 minutes corresponds to the steady-state between erosion and uplift during the first phase of uniform rainfall. Note the progressive shortening and steepening of the channel once the rainfall gradient is applied and the existence of a temporary steady-state before splitting occurred. $\mathbf{d}$, Detailed elevation history of three selected points of the landscape. Point $A$ is located in a channel and it remains in the channel during the entire experiment. After the application of the rainfall gradient, its elevation first increases but rapidly stabilizes during the temporary steady-state; it is finally uplifted after splitting occurred. Point B is located on a permanent hillcrest that separates two main drainage basins. It is continuously uplifted after the application of the rainfall gradient. The evolution of point $\mathrm{C}$ is a combination of histories of points $\mathrm{A}$ and $\mathrm{B}$. It corresponds to a channel with a similar evolution than A until splitting occurred. It is then uplifted and ends on a hillcrest that divides up a former single drainage basin into two individual ones. Dotted lines show the trend of applied uplift ("rock uplift") and therefore indicate the elevation of points that are passively uplifted, i.e. where no erosion occurred.

Figure 4 Model of drainage basin response to drainage divide migration (see text for comments). Blue colours show active streams, whereas orange colours show hypothetical floodplain deposits. Note that some of these deposits can be passively uplifted and observed on the hillcrest separating two newly-formed drainage basins. These deposits would be classically interpreted as resulting from relief inversion or river capture.

Figure 5 Topography and drainage networks of the Sierra Aconquija, northwestern Argentina. a, Map showing the topography of the Sierra Aconquija, major tectonic elements and mean annual precipitation (dotted blue lines, in $\mathrm{mm} \mathrm{yr}^{-1}$; after ref. 10). $\mathbf{b}$, Perspective view highlighting the topographic asymmetry of the range. $\mathbf{c}$, Images showing examples of drainage networks located on the driest side of the Sierra Aconquija where different stages of drainage splitting likely are represented, following the model shown in Fig. 4 (images from OpenAerialMap.org, except 1\&2: GoogleEarth). Examples 1 and 2 are cases where two tributary streams do not connect at valleys' junction, but flow separately within a single valley floor (open arrows). The same configuration is observed in example 3, except that the two parallel-flowing streams are separated by elevated fluvial deposits (solid arrow) whose mapping ${ }^{30}$ shows that they constituted a single alluvial body that extended upstream along the two streams. Consequently, it likely represents an example where 
333 drainage splitting is associated to the nascent of a new hillcrest. Example 4 shows the case of a

334 hillcrest (solid arrow) separating two drainage basins whose outlets are very close and whose general 335 shapes suggest that they initially formed a single drainage basin. This assumption is reinforced by the 336 abrupt change in the flowpath direction of one river, suggesting a former connection between the 337 two drainage basins (white dotted line), and by the existence of a system of alluvial fans whose size 338 suggests feeding by a basin larger than the two present ones. This last example would thus represent 339 the ultimate case of the splitting mechanism.

341 Supplementary Figure. Spacing of drainage basin outlets of experimental landscapes plotted

342 against drainage basin lengths. The linear relationship shown here is similar to the trend observed in 343 natural landscapes ${ }^{9}$. The linear fit defines a spacing ratio (ratio between the spacing and the length ${ }^{9}$ ) 344 of 2.22, whereas the values range between 1.91 and 2.23 in natural landscapes ${ }^{9}$. 
PREPRINT / Bonnet, Nature geoscience, 2, 766-771, 2009.
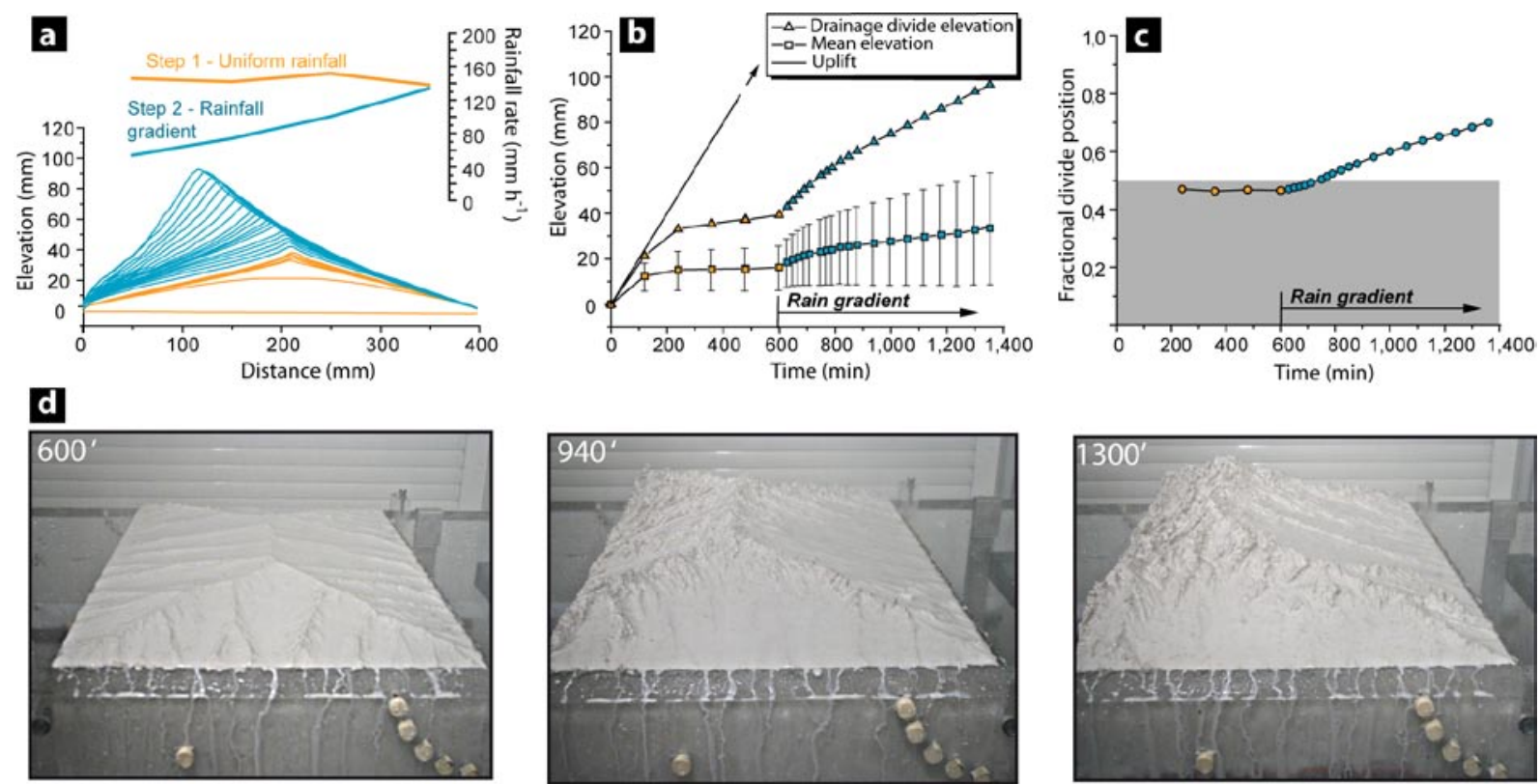

NGS-2009-06-00693 
PREPRINT / Bonnet, Nature geoscience, 2, 766-771, 2009.
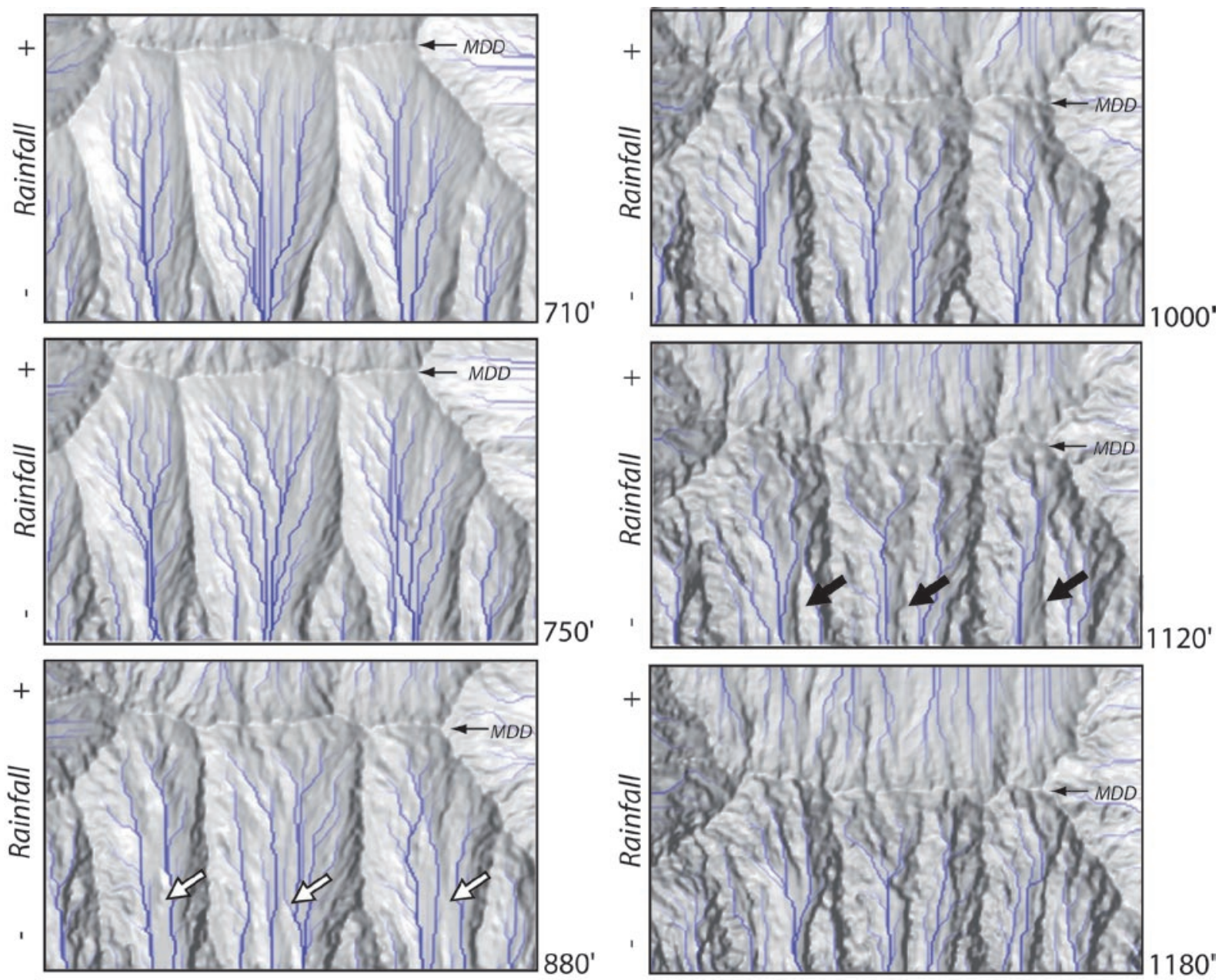

NGS-2009-06-00693

BONNET Figure 2 
PREPRINT / Bonnet, Nature geoscience, 2, 766-771, 2009.

\section{a}
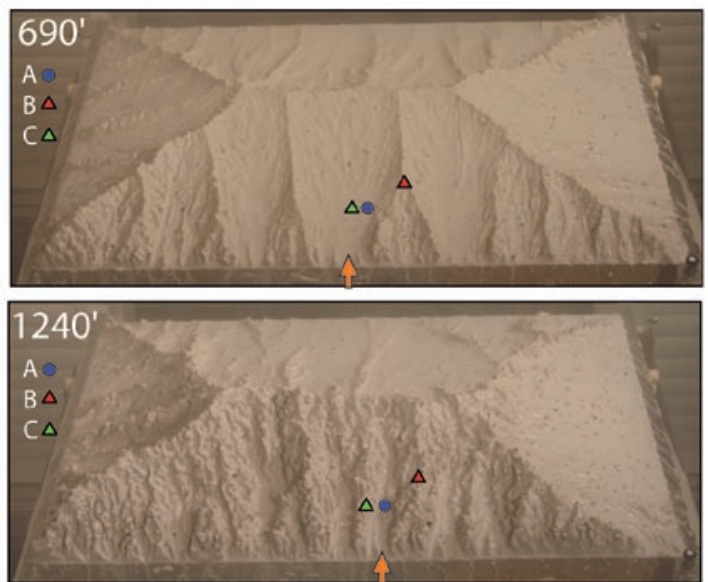

c

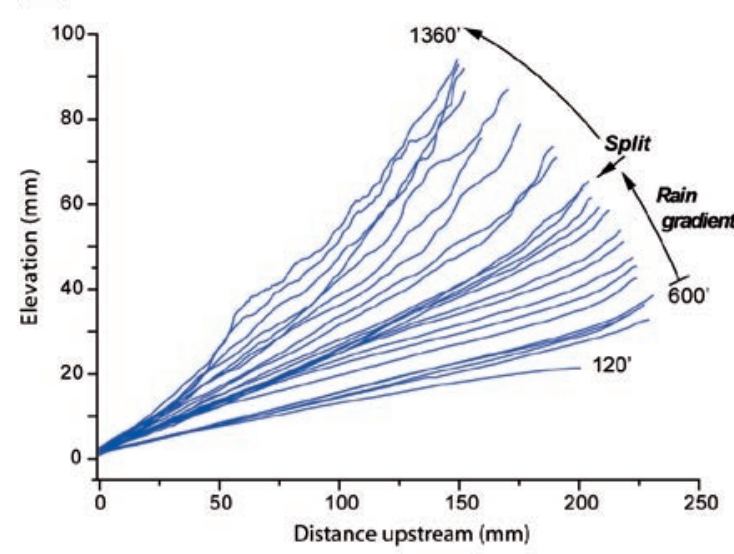

NGS-2009-06-00693

BONNET Figure 3 b

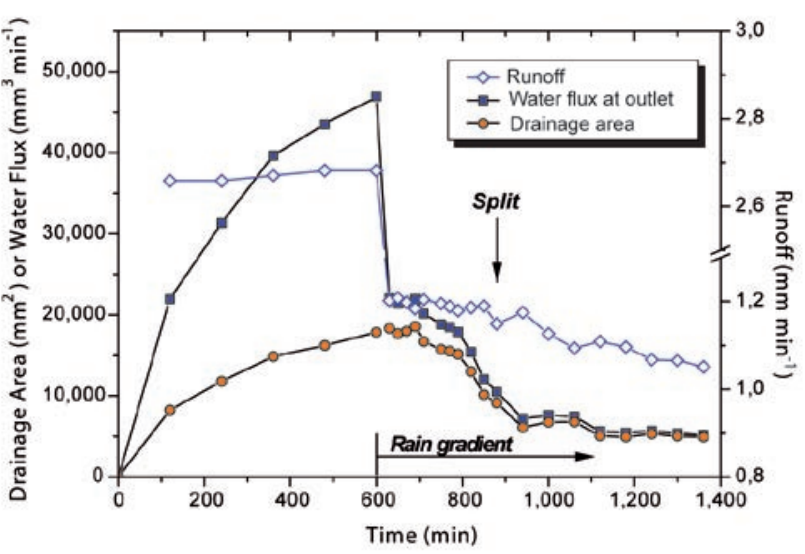

d

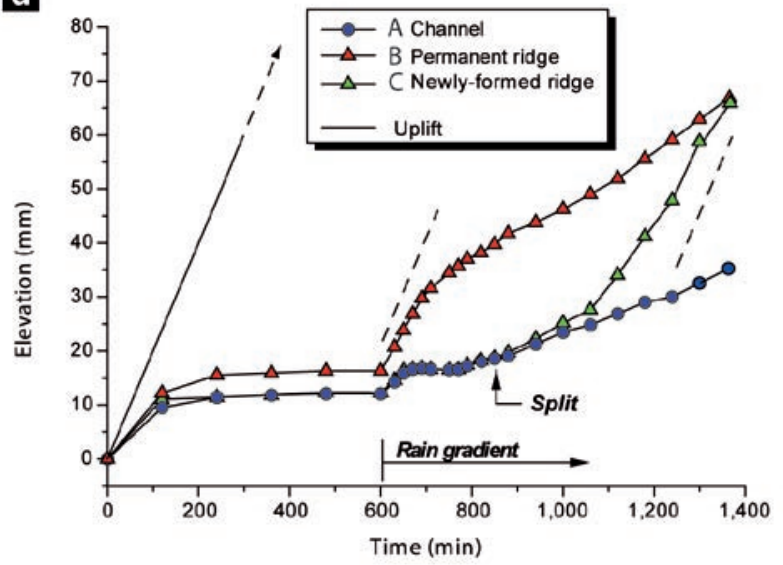


PREPRINT / Bonnet, Nature geoscience, 2, 766-771, 2009.

DIVIDE MIGRATION: continuous reduction of discharge and channel width

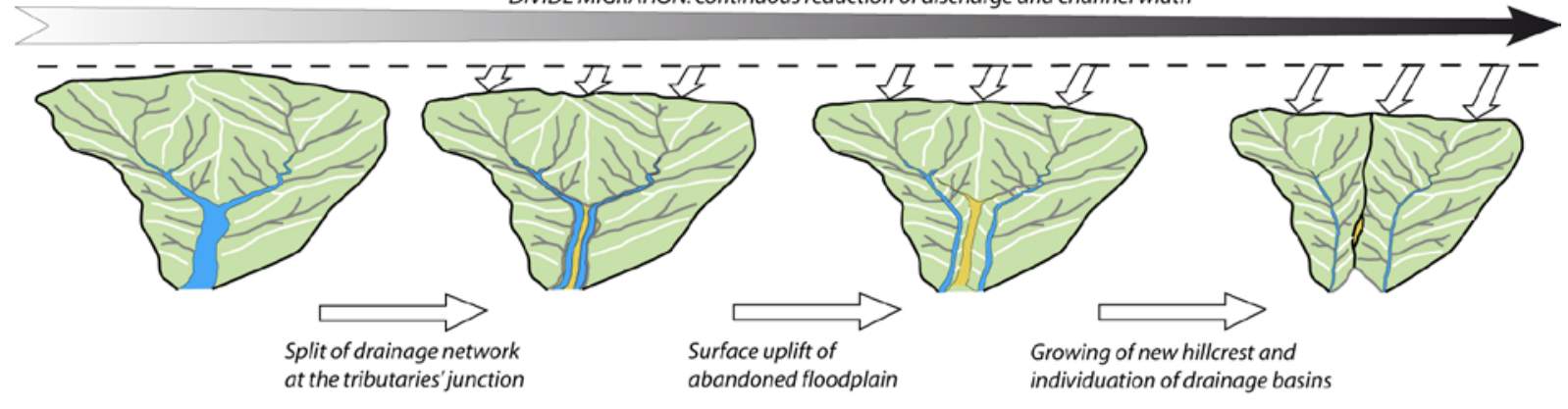

NGS-2009-06-00693

350

BONNET Figure 4 
PREPRINT / Bonnet, Nature geoscience, 2, 766-771, 2009.

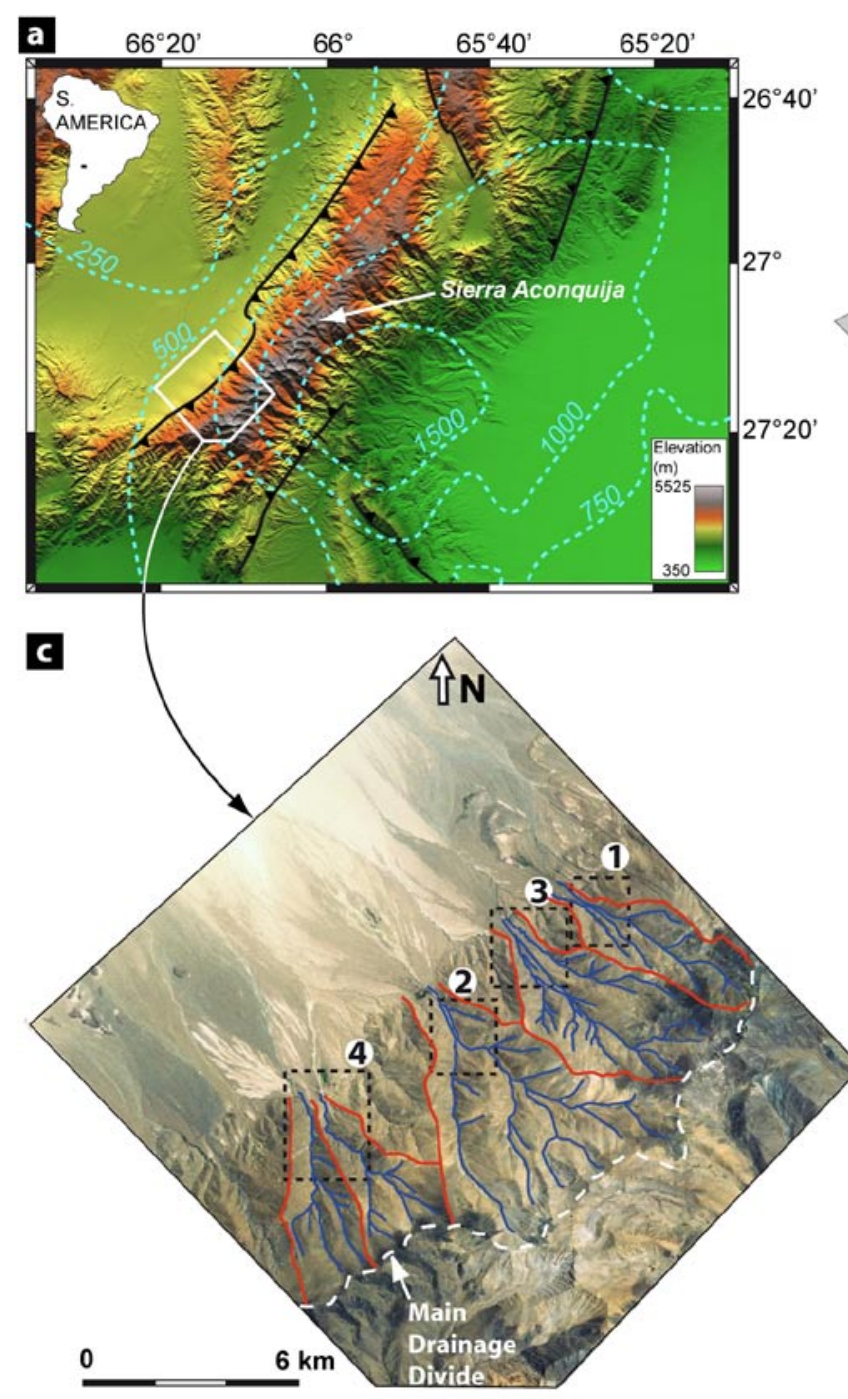

b
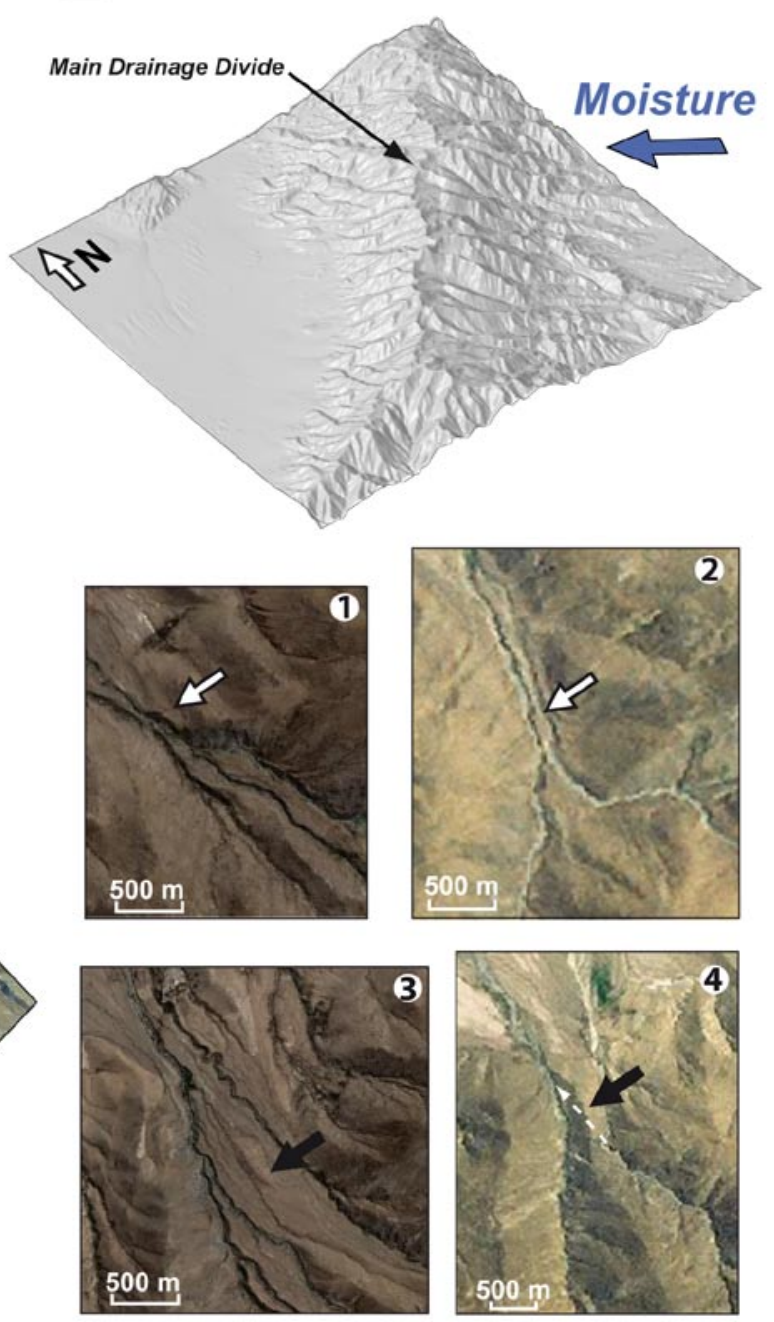

NGS-2009-06-00693

BONNET Figure 5 